\title{
Japanese And Western Management Approaches: Is Convergence Occurring?
}

Edwin C. Duerr, (E-mail: eduerr@sfsu.edu), San Francisco State University and Aarhus School of Business, Denmark Mitsuko Saito Duerr, (Email: eduerr@sfsu.edu), San Francisco State University and Aarhus School of Business, Denmark

\begin{abstract}
Japan's rapid economic growth in the 1970s and 1980s, and the success of a number of Japanese factories overseas, led to great interest in the Japanese managerial system and some specific techniques used by Japanese companies. A plethora of books and articles were written about the value of (or threat from) Japanese business-government cooperation, the Japanese employment system and management-labor cooperation, the avoidance of excessive competition, the wide use of long-term relationships and planning, and the emphasis on growth rather than short-term profits. There was also much written about specific Japanese techniques including the use of quality circles, continuous improvement, total quality management, flexible production, and just-in-time and lean production. Many European, Canadian, and U.S. companies adopted some of the most widely publicized Japanese techniques, often in substantially modified form. Important aspects of production and logistics were revolutionized. Some companies also used modified Japanese approaches in attempting to improve management-labor relations.
\end{abstract}

In Japan, the economic problems from the 1990s to the present, and the success of some foreign firms, led to increased interest in Western management approaches. There was growing concern that the traditional Japanese ways of doing business were inadequate to cope with the changing international and domestic environments. During the past decade, there has been wide discussion in the business press of the need for adopting selected Western methods. A number of Japanese companies have announced that they are changing their traditional employment practices, and mergers and acquisitions have become increasingly common. It thus might appear that Japanese and Western managerial philosophy and approaches are converging.

While Japan and the West have each benefited substantially from the adoption of ideas and techniques from the other, basic differences remain in the values, beliefs, and objectives of business, government, and society. In this paper, these differences are discussed, and the degree of convergence is seen to be limited more to techniques than to the basic assumptions, objectives, and strategies that drive business.

\subsection{Introduction}

apan and the Western countries (Europe, the U.S., Canada, etc.) all have long histories of studying the ideas, technologies, and organizational structures from other countries. Those that have appeared to offer potential for meeting domestic governmental, societal, business and/or individual needs and objectives were adopted, after being modified to suit the adopting country's environment and beliefs. The interchanges of approaches and methods have resulted in great improvements in productivity and standards of living in all of the countries.

The early United States, a relative latecomer in development, obtained virtually all of its initial technology from Western European nations (by a variety of overt and covert methods). Basic ideas, values and beliefs were

Readers with comments or questions are encouraged to contact the authors via email. strongly influenced by the European heritage, drawing on a wide variety of experiences and philosophies. Of partic- 
ular importance for the U.S. were the values placed on individual rights and responsibilities, competition, and the rights of owners of property. (Duerr, 1991)

\subsection{Japan's History Of Learning From Abroad}

Japan has been particularly adept at learning from abroad and then making improvements in the borrowed processes and products. In the $8^{\text {th }}$ and $9^{\text {th }}$ centuries, Chinese knowledge and practices provided the base for Japan's early advances in science (metallurgy, woodworking, construction of large building, lacquer-ware manufacturing), in religion (Buddhist and Confucian additions to native Shinto), in governmental organization, and in developing a written language. Chinese thought tended to reinforce a number of existing Japanese values and beliefs: the acceptance of hierarchy as natural and pervasive, the importance of subordinating individual desires for the benefit of the group/family, the emphasis on duties and obligations rather than on rights, and a belief in the value of cooperation for mutual benefit.

In this learning process, Japan assimilated the ideas and techniques it wanted, and adjusted them to fit its own basic values. In spite of modeling the Japanese government on that of China, the Japanese used their traditional system of selecting officials based on family and heredity rather than on examinations. They also partially changed the Confucian emphasis on the loyalty to the family as the paramount value. While the Japanese continued to stress the virtue/ necessity of individuals subordinating their desires for the good of the family, they placed loyalty to the local lord and to the nation as being of even greater virtue/necessity. (Reischauer, 1995)

During the $16^{\text {th }}$ century, the Japanese learned (and improved upon) the manufacture of guns, and learned improved smelting techniques after Westerners reached Japan. Contact with the West, and the manufacture of guns, was prohibited early in the $17^{\text {th }}$ century. (Scher, 1993)

In 1953, the arrival of warships from America led to Japan's ending of over 200 years of isolation from the rest of the world. This, in turn, led to a change in government in 1868 (the Meiji Restoration) and some restoration of power to the emperor. The new government, comprised of members of the governing class (samurai) stressed the traditional values of cooperation, hierarchical relationships, loyalty, duty to superiors and to the state, the deity of the emperor and the nation's unbroken imperial line. The new leaders perceived that in order to maintain their nation's independence in the face of Western imperialism, they needed a more modern political system, a stronger economy, and a more modern military. This required learning form the West. The government sent delegations abroad to study foreign technology, education, medicine, military science, and government structures. After determining which countries seemed to be the most advanced in each field, and the most suitable for adaptation to the Japanese environment and objectives, they set about to learn and modify. The British system of government seemed most appropriate so they used it as the model for their own government structure, but changed it to show that the emperor as the source of all legitimacy, authority, and power. The German medical system was considered to be the best in the world and was adopted (prescriptions in Japan are still written in the German language).

Western technology was actively sought, and the Japanese government invited foreign experts to come to assist them in industrial development as well as in other fields. In all of these endeavors the Japanese stressed "Western technology, Japanese spirit." Key ideas were added during this period: Japan is a poor nation with limited resources that must export to survive; private business exists to support the nation; and entrepreneurship and business are honorable pursuits valuable to the nation. (Duerr, 1991, pp. 45-51) While some of the more liberal Western social and political ideas were discussed and tried, those that did not fit Japanese values were modified, limited, or suppressed.

After the end of World War II in 1945, Japan again sought Western technology. "Japan imported virtually all the technology for its basic and high-growth industries, and it imported the greater portion of this technology from the United States." (Johnson, 1982, p. 16) The Japanese government facilitated the acquisition of technology from abroad and assured that Japanese companies did not pay too high a price for it. The government had a strong industrial policy centered on economic growth rather than on social goals, with the primary objective of reviving and expanding basic manufacturing industries. (Hsu, 1994, 174) Private industry, guided and assisted by the gov- 
ernment, was seen as the effective and desirable tool for achieving growth. (Duerr, 1991) The Japanese government, particularly the Ministry of International Trade and Industry and the Ministry of Finance, provided protection from imports (through quotas, tariffs, technical standards, inspections, etc.) as well as access to capital, and direct or indirect subsidies in some cases. (Duerr, 2002)

Japanese industries also studied American managerial techniques and approaches. The Occupation Forces in Japan (primarily American) published articles about the effects of psychological and sociological factors on worker motivation, and the benefits to companies of encouraging worker involvement. The Japanese, not realizing that these ideas were little used in the U.S., saw their value and went on to extend employee involvement to the worker level. Georges Demming lectured about quality control in Japan, and found management there much more receptive to his ideas than American companies had been. Over time, these ideas were combined and developed in to quality circles and systems of total quality management. Japanese companies sent a number of study teams abroad to study American and European technology and management techniques. Toyota had studied the Ford production system extensively before and after WWII. It added its own ideas to what it learned and went on to develop the just-in-time and lean production systems. (Duerr, 2002, 9)

Part of the reason that the large Japanese manufacturing companies were able to use these techniques so effectively was the 'lifetime' employment system. This system provided permanent employment until retirement for all regular workers in large companies, regardless of changes in company needs after they were hired. The system, in limited use since the $17^{\text {th }}$ century, had been extended to all managers in large companies after World War I, and then to all regular workers at large companies after World War II. (Scher, 1993) Regular workers were expected to give total loyalty and maximum effort to their companies. (Duerr, 1998)

Japanese industries that had the potential for exporting, and their employees, worked hard to improve productivity and quality so that could sell their products overseas. The companies were driven by national economic objectives/patriotism, and by the desire for status and security to be derived from exporting and larger sales. The employees perceived their status and income to be dependent upon the success and size of the companies for which they worked, and thus their efforts in improving quality and productivity. The employment system ensured that increases in productivity and/or quality would not result in layoffs.

Combining knowledge of the technology and systems learned from the West with their own values/beliefs/objectives and innovations in management, Japan enjoyed the highest growth rate of any industrialized nation from 1945 to 1990. In 1990, a crash in the Japanese stock market and a severe decline in land prices ushered in a period of economic malaise that has continued to the present time. (Duerr, 2002) This has led to widespread concern in Japanese government and business circles that the approaches used by Japan since 1945 are not adequate to deal with the changing international competitive environment. The business press and comments by the government indicate the need for Japanese business to once again learn from the West. Some examples of what they are learning, and what they appear to be rejecting, are given in Section 3.

\subsection{Learning From Japan By Western Companies}

Western companies were slow to begin learning from Japan, recognizing an economic threat without seeing a way to meet it. Japanese companies expanded export sales rapidly after 1950, and from the late 1970s onward the nation had increasingly large export surpluses. The U.S. and Europe (and some other nations) became increasingly concerned with the imbalance that was seen as taking jobs away from other nations. Many Western companies found Japanese competitors cutting in to both their domestic and their traditional export markets. Over 347,000 jobs in America's automobile industry were lost as imports from Japan took an increasing share of the U.S. market. (Wong, 1989, 87) Shoe, textile, and electronics industries lost sales, profits, and jobs to Japanese exports. European nations raised barriers against Japanese goods, with Italy instituting "46 import quotas directed specifically against them." (Japan, Inc., 1971, 50)

Initial responses to Japan's increasing dominance in a number of industries and growing trade surpluses 
were to place blame on Japanese policies or, at least in the case of the U.S., to blame Western labor. It was not until the 1980's that a substantial number of Western companies came to realize that some carefully selected and modified Japanese approaches could serve to improve quality and productivity in the West using local labor.

\subsubsection{Attempting To Assign Blame}

The Japanese were accused of dumping products abroad, of maintaining restrictive trade barriers in Japan, and of government, business, and labor conspiring to dominate world business. (Wolf, 1983; and many others) Suggested methods of coping with the Japanese trade surpluses included emulating their industrial policy, adopting their cooperative management-labor system, and retaliating to force Japan to further open its markets. However, none of these approaches appeared to be an offer a feasible solution. Industrial policy didn't seem to be providing enough jobs or high economic growth rates in Europe. The U.S. and several European countries could not see a way to achieve similar cooperation between labor and management. Repeated efforts to open Japan's markets resulted in only slow progress, and America's reliance on Japan as an ally and base for military operations precluded taking stronger trade actions.

In a number of American companies, management blamed worker attitudes and the power of the unions for low productivity and quality problems. There was a feeling that there was no way that Americans could compete with Japanese workers who were viewed as dedicating themselves to work while requiring relatively low pay.

\subsubsection{Recognizing The Feasibility Of Learning From Japan}

Attitudes in the U.S. and Europe began to change when Japanese companies began to open manufacturing facilities in those countries. Some electronics companies were among the first to begin local manufacturing, but the arrival of the automobile manufacturers in the early 1980s clearly demonstrated that Japanese management could achieve high levels of both quality and productivity with local labor. Japanese automobile plants in the U.S. achieved higher levels of both quality and productivity than most U.S. factories. Nissan's U.K. factory attained the highest level of productivity of any automobile plant in Europe.

Companies in the West began to look more closely at both the ways in which Japanese managed the local workforces and some of the specific techniques they used in improving quality, increasing productivity, and lowering costs.

Some examples of learning by both Western and Japanese companies, and the limits of transference of systems and techniques, are discussed in Section 3 below. First, however, it is useful to look at some of the key characteristics that differentiate Western and Japanese managerial styles.

\subsection{Selected Features Of 'Japanese Management'?}

The Japanese business and economic system is built on a different set of values, beliefs, and objectives than those in the West. Of course there are also significant variations in business environments, structures, and practices among the Western countries. For example, labor regulations, labor relations, union objectives and structures, requirements regarding worker representation on boards of directors, and government regulation of business vary greatly between Sweden, France, Germany, the U.K., and the U.S. (Crane, 2000; Lane, 1989) However, the differences between Japan and the Western nations are much greater than those between the Western nations themselves.

A detailed examination of the differences in management systems is beyond the scope of this paper. A number of books discussing the characteristics of Japanese management systems are available, from Yoshino's groundbreaking Japan's Managerial System (1968) through Abegglen's Kaisha, The Japanese Corporation (1985) and Yoshimura's Inside the Kaisha (1997) to Bird's Encyclopaedia of Japanese Business and Management (2000). There are also a number of books which provide explanations of the cultural and institutional bases underlying business practices, such as Hendry's Understanding Japanese Society (1995) and Reischauer's The Japanese Today: Change and Continuity (1998). However, some of the key differences will be discussed briefly. 


\subsection{Some Key Features}

In Japan:

- $\quad$ There is a heavy emphasis on the importance of the group. The individual is less important than the organization to which he/she belongs. The individual is expected to subordinate his/her desires for the benefit of the group.

- The individual derives his/her status primarily from the groups with which he/she is affiliated (schools from which graduated; company or government organization by which he, or her husband is employed; and also from his or her husband's position in the organization).

- $\quad$ Hierarchy is considered natural and desirable, and a high level of deference to more senior (higher status) individuals and organizations is expected. There is a hierarchy of organizations as well as of individuals. In general, larger companies have more status than smaller companies. The national bureaucracies are at the top of the hierarchy, and there is a hierarchy among the bureaucracies. Japanese meeting for the first time exchange business cards, partly in order to determine their relative status so that they will know what speech forms to use with each other.

- In larger organizations, both business and government, there is widespread input to decision making and widespread acceptance for and support of decisions made. Though Westerners sometimes find it difficult to reconcile this with the hierarchial structures, input doesn't necessarily mean control of final decision. Decision making thus tends to be very slow, but implementation fast.

- There is an emphasis on long-term relationships and mutual obligations. There is more of a reliance on compatibility, trust and mutual benefit in business relations, and less faith in contracts, than in the West.

- In most organizations, the status and income of the individual are directly related to the success of the organization.

- In spite of recent discussions of greater labor mobility for some people in Japan, the great majority of individuals cannot change jobs without losing both status and income.

Socialization both at home and in school emphasizes the importance of the group, the importance of fitting in, hard work, a willingness to sacrifice for the good of the group/organization/nation, and rote learning rather than individuality and standing out from the group (Hendry, 1995, chapters 2,3,6). The result is "a well-socialized and committed work force" (White, 1987, 2), but one in which individual actions and initiatives are not encouraged.

\subsection{Examples Of Characteristics In Action}

One of the most obvious differences in Japanese companies is the expectation that university-educated employees (and other male white-collar employees) will work long hours of overtime without additional pay, and that they will give up substantial portions of their vacation time without being paid for doing so. The authors of this paper conducted a 6-year study that surveyed 94 participants in 47 Japanese organizations and found that, on the average, each employee worked 12.6 hours of unpaid overtime per week and gave up $28 \%$ of his vacation entitlement without pay. (Duerr, 1998) These figures are consistent with statistics published periodically by the Japanese government.

Many Europeans and Americans find it difficult to understand why Japanese employees are willing to do this. However, Americans who intend to pursue careers in law or accounting, or who want to advance rapidly in management, may routinely expect put in very long hours in order to succeed. In all countries, entrepreneurs and small business owners must often put in long hours without extra compensation if they are to be successful --- but 
they do not normally expect their employees to do so without additional pay (or stock options).

Almost all male Japanese university graduates and white collar workers expect to put in long hours. Their education and company indoctrination have given them values that support this, their status and income are tied to how well their companies do, and they worry about failing to progress in their organizations if they do not show the proper dedication. (Yoshimura, 1997)

Another example of differences between Japan and the West involves the slow Japanese decision-making process and expectation for rapid implementation. In the negotiations for the formation of NUMMI, discussed below, General Motors sent only a few top executives to Japan to look at Toyota's operations. GM soon decided that a joint venture was desirable. Toyota sent a number of study groups, including many managers, to look in detail at General Motors' operations. GM became very concerned when Toyota took a very long time before deciding whether or not to develop a joint venture. They worried that Toyota was really trying to spy on them rather than reach an agreement. It became Toyota's turn to worry when Toyota finally said that they would like to form a joint venture, and GM said they could not possibly act as quickly as Toyota's time table proposed.

The problem was one of decision-making methods. General Motors had sent their key decision- makers, who decided it was advantageous for GM, and then wanted to negotiate a contract promptly. However, since relatively few GM executives had been involved, getting to the actual implementation stage would require a long further detailed planning --- which they would not undertake until an agreement was reached. Toyota, on the other hand, had sent the key executives and managers from all areas that would be affected by the joint venture. Back home in Japan, they had discussed the proposal, and the actions each segment of the company would have to take to implement it, in detail. Once they decided to agree to the joint venture they were immediately prepared to move ahead, while GM still had much planning to do. Fortunately, the two parties came to understand what had happened and went on to form a highly successful joint venture.

\subsection{Examples Of Learning From Abroad}

While the most widely discussed examples of learning from abroad have been in manufacturing, marketing has also been greatly influenced by the application of approaches used abroad.

\subsection{Manufacturing}

Specific techniques of Japanese management, such as quality circles, were tried by a number of American companies in the late 1970s and the early 1980s. (Dessler, 1983, 94). Application of more comprehensive approaches such as just-in-time production, total quality control, and flexible manufacturing lagged except in some U.S. subsidiaries of Japanese companies. (Schonberger, 1982, 83; Gelsanliter, 1992, 84) It began to become clear that some of the more broad Japanese concepts could be successfully applied in the U.S. when Japanese automobile companies opened factories in America. Honda opened a plant in Marysville, Ohio in 1982 and Nissan began production in Smyra, Tennessee in 1983. These wholly-owned facilities achieved high levels of productivity and quality, and received as substantial amount of publicity. A greater impact, however, resulted from the formation of New United Motors Manufacturing Inc., a joint venture of Toyota Motor Corporation and General Motors Corporation.

Toyota's objectives were to: (1) gain experience with unionized American labor; (2) gain experience with American suppliers; and (3) help diffuse the trade issue between the U.S. and Japan. General Motors two main objectives were to gain experience with the extremely efficient and cost-effective production system, and to obtain high quality automobiles for its Chevrolet division. (Community, 1990, 1\&3) Toyota assumed responsibility for production and General Motors for marketing. The physical facility used was a closed GM plant that had been shut down for two years because of poor productivity, poor quality, high absenteeism, and poor labor relations.

Toyota's approach centered on a managerial approach, using a number of elements of the Japanese style, rather than technology. Working with the United Automobile Workers union, they developed a new type of labor contract stressing cooperation, the strongest job security in the industry, and a no-strike clause. They carefully se- 
lected workers on the basis of attitudes and willingness to learn and to work cooperatively as well as for skills. Most of those selected were people who had worked in the plant under GM management until the factory was closed in 1982. Few had found similarly high-paying jobs in the interim. NUMMI provided extensive training (including sending approximately $10 \%$ of the workforce to Japan for training), introduced a team approach to work, and developed new relationships between employees and supervisors. Employees were given the responsibility for quality control, and the authority (and responsibility) to shut down the line if there were quality problems. In recognition of American preference for equality in relationships, there were no reserved spaces in the employee parking lot and all employees ate in the same lunchroom, though this is not the case in Japan where a stress on hierarchy is pervasive and considered natural. (Duerr, 1992) The company used consensus decision-making, worker involvement in production decisions and control, a modified just-in-time inventory system, worker responsibility for participation in problem-solving, a stress on continuous improvement, and consensus decision making. Supervisors and union representatives jointly worked to resolve disagreements. (Duerr and Duerr, 1991)

The short run results were impressive. The NUMMI plant quickly became $40 \%$ more productive than the average American automobile manufacturing facility, the cars obtained excellent quality ratings by J. D. Powers, absenteeism dropped drastically, and labor relations improved dramatically. (Duerr, 1992) The long run results have shown that the somewhat-modified Japanese model continues to work. Employment has grown from 2,000 employees to 5,100 employees as light trucks and an additional car model have been added to the lineup and output has climbed from 65,000 to 375,000 vehicles per year. The new Pontiac Vibe is scheduled to be exported to Japan as well as to be sold in the U.S. All of the key elements of the original approach are still in use: consensus decision making, channels for staff feedback, the just-in-time inventory system, use of production teams, worker responsibility for quality and improvements, cultivation of a sense of equality, and cooperative management-labor relations. (Armstrong, 2002, G1\&G6)

Both General Motors and Toyota learned from the joint venture, but the lessons learned were somewhat easier for Toyota to apply. General Motors had a number of executives and managers work at the NUMMI plant, and hundreds visit it. An hour-long telephone conversation by the authors with a senior executive who had worked at NUMMI indicated some problems --- not in NUMMI, but in selling the idea elsewhere in GM. Those who had worked at the plant were impressed with the success of the cooperative approach and worker input. But it was difficult to convince other managers in the company that labor would really put in the required effort under such a system. (Duerr, 1992) Workers at other GM plants, with their long history of adversarial relations with management, were suspicious of a supposedly cooperative and trusting relationship. Specific Japanese techniques were modified and adopted by General Motors Management, but overall 'Japanese-style' labor-management cooperation could not be achieved.

General Motors had to set up a separate and 'new type' of automobile company, Saturn, in order to apply all that they had learned and institute an overall system with labor-management cooperation. General Motors employees could join Saturn, but had to give up their positions and seniority with GM. A number did so, and both the automobiles and the company have been a success. The company did not offer a promise of lifetime employment.

Toyota did learn how to deal with American suppliers and with a unionized American workforce. When they subsequently opened a wholly-owned plant in Georgetown, Kentucky, they used a management team trained at NUMMI, and followed similar policies in selection, training, sharing of information, and the team approach. At the Kentucky facility, they used non-union labor.

Another interesting example of reciprocal learning involves Renault and Nissan. Nissan had been highly successful in Europe, providing a model for the European automobile industry, during a period when Renault had some significant problems. However, Nissan suffered major losses in the 1990s in its homeland of Japan and was in

danger of going bankrupt in 1999 when Renault took a controlling interest in Nissan and made changes that returned it to profitability.

Nissan had decided in 1984 to establish its first European assembly plant in Sunderland in the northeast re- 
gion of England. Building on their experiences in the U.S., they wanted an area with long-standing unemployment, a relatively ethnically homogeneous population, and government subsidies. While the British automobile industry is plagued by a multiplicity of unions, Nissan was willing to build the plant only if they could have just one union, with both workers and supervisors belonging to it. The AEU, representing the unions, agreed to a one-union plant, rather than not have the company at all. (Oliver, 1992; Nissan UK, 1995)

Nissan Motors UK promised lifetime employment. This proved expensive during a 1993 recession, but the company did live up to its promise while reducing its workforce somewhat by giving six months salary as an incentive for voluntary departures. The company carried over some practices from its successful U.S. plant (single cafeteria and recreational facilities, near absence of private offices). It worked cooperatively with labor, stressing widespread input to decision making, teamwork, flexibility, continuous training, continuous improvement, and working with the union. It helped suppliers to develop their own R\&D capabilities, provided training programs for them, and signed long-term contracts calling for quality improvements and price reductions over time. They came to be recognized as Europe's benchmark automobile manufacturer. In 2000, Nissan's UK plant was recognized as the most productive in Europe. (Griffiths, 2001, 5)

While Nissan's UK plant was performing so well that visitors came from all over the world to see its operations, the parent company was nearing bankruptcy. It had lost money in every year but one in the 1990s, with a $\$ 5.7$ billion loss in the year ending March 31,2000. It was plagued by a bureaucracy resistant to change, engineers who designed what they wanted to make without an adequate understanding of what consumers wanted, excess manufacturing facilities, and excess labor.

In 1999, Renault purchased a controlling 36.8\% interest in Nissan, and installed Carlos Ghosn as President. Ghosn enlisted the aid of both managers and workers in formulating a revival plan, creating nine cross-functional teams. He announced plans for closing plants and for a large reduction in the workforce. He relied primarily on workforce transfers and voluntary retirements rather than on laying-off workers as Nissan downsized. Purchasing costs were reduced, a merit pay system introduced, internal bureaucracy reduced, and some production transferred overseas. The changes resulted in a remarkable turnaround and a profit of \$2.9 billion for Nissan in 2001.

Ford had taken a controlling 34\% interest in Mazda before Renault took over Nissan. The American-style approach of Ford's first president of Mazda led to conflict with the union. His successor took a more Japanese approach, involving many managers and soliciting suggestions from the workforce. Even with this approach it took 6 months to get the union to agree to the restructuring plan and Mazda has not made as much progress as Nissan. (Mazda, 2000,11; Burt, 2002, 11).

\subsection{Marketing}

Japan's complex, expensive, and semi-closed marketing system was viewed by foreign companies, and by foreign government trade representatives, as a serious impediment to selling to Japan. It dissuaded many companies from even attempting to sell to Japan. It resulted in such high prices for some imported consumer goods, particularly luxury items, that sales levels were kept low. The system is characterized by a very large number of small retailers and by multiple layers of wholesalers. Before the bursting of the economic bubble, Japan had twice as many retailers per capita and twice as many wholesalers per capita as the United States. Though most wholesalers operated on small margins, the sum total of their costs contributed to Japan's having the highest prices in the world for most consumer goods. Additionally, some channels were effectively closed to outsiders because of traditional relationships and preferences for only dealing with those with whom there were long-standing relationships. Companies in some of the channels that did handle foreign consumer goods believed that high prices gave prestige to the products, and that lower prices would result in decreased sales. Wholesalers often provided credit to small retailers (and also to smaller wholesalers, and sometimes to small manufacturers). Manufacturers of clothing and some other goods allowed returns of merchandise that simply because it did not sell well, even if it was not defective. A number of European luxury goods manufacturers did open a small number of outlets successfully. For most foreign companies, entering the retail market in Japan simply did not appear to be feasible. 
There were some early successes by foreign companies. Mitsubishi Trading Company approached Kentucky Fried Chicken about a possible joint venture. Mitsubishi was already a large importer of grain, had started its own chicken raising operations, and was looking for more markets for its chickens. It identified KFC as the largest single purchaser of chickens in the U.S. With its semi-assembly-line type of operation, high volume, and low prices made possible by the system, the KFC operation seemed very promising to Mitsubishi. The American president of the joint venture, Loy Weston, adjusted to Japanese customs in hiring, training, employment, attention to quality and cleanliness, and advertising approaches. He did decide on one innovation, not used in the U.S., of having a life-size figure of Colonel Sanders in front of every restaurant to demonstrate that it was a genuine KFC store. The partnership of Mitsubishi and KFC introduced a new type of restaurant into Japan and has been highly successful.

McDonalds was an early innovator. The company believed that the Japanese would be willing to change their traditional unwillingness to eat on the street (except in parks or temple grounds) if given a new type of fast food store/restaurant with inexpensive, and food of consistent quality which could easily be held. The chain was so successful that its earnings in Japan actually became larger than the earnings in the U.S. McDonalds success spawned several imitators in Japan, but remains the market leader. KFC and McDonalds introduced a new type of fast-food chain to Japan, and together with Japanese competitors, provided additional choices for Japanese consumers.

A number of other foreign restaurant chains and specialty food stores, such as Denny's, Dunkin Donuts, etc., have successfully opened operations in Japan.

The 7-Eleven chain of convenience stores introduced both a new kind of store and a new marketing channel to Japan. It was originally an American company, owned by Southland Corporation. Southland had recognized the need in the U.S. for stores to meet the needs of dual wage-earner families and people working non-standard hours. The increasingly affluent U.S. public had proved to be willing to pay somewhat higher prices for the convenience of shopping at off-hours. The chain achieved high revenue per square foot by care in selecting and monitoring the mix of products, controlling inventories, and using frequent deliveries. In looking at the complex Japanese distribution system, they saw an opportunity rather than a problem: since the system there was too complex and expensive, they would set up their own system. 7-Eleven entered a partnership with Japan's Ito-Yokado to create 7-Eleven Japan in 1973. The joint venture set up its own distribution system including warehouses and delivery trucks. When Southland had some problems in the U.S., it sold its share of 7-Eleven Japan to Ito-Yokado, and eventually Ito-Yokado purchased a controlling interest in Southland Corporation itself. 7-Eleven's success in Japan resulted in the development of a number of competitors and made a substantial change in Japanese retailing. The company continues to innovate in inventory control, product selection, and the introduction of new services. It remains the market leader in Japan, and had profits of US\$1.3 billion in the year ending February 2000. (Kuo, 2002)

Toys R Us, like 7-Eleven, decided to go around the complex Japanese distribution system. They intended to establish a chain of toy stores that could sell a larger variety of goods at prices lower than the typical smaller Japanese toy stores by buying directly from manufacturers. This proved to be more difficult than they had expected, as most manufacturers were unwilling to bypass their regular wholesalers. Concern over being dumped by their regular wholesalers, and the need for financing from them in some cases, caused this reluctance. After some period of problems they were able to get some manufacturers to sell directly to them.

In recent years, though Japan's economy was (and still is) in a slump with declining consumer spending and falling prices, other foreign companies have entered the market with new ideas or approaches. Looking at the declining prices for land and rental, and the high prices of their products in Japanese retail stores caused by the expensive distribution system, GAP opened a retail outlet in Tokyo. They provided opportunities for women in management, as well as part time openings for women attending college. Through careful selection and training, they were able to provide a more informal and relaxed atmosphere in their stores than the typical Japanese store, without sacrificing required politeness and service. The success of their first store has led to a rapid expansion in Japan.

The American concept of the shopping mall has been introduced to Japan, with adjustments for population distribution and transportation availability, with great success. Starbucks has been successful in entering the Japa- 
nese market and is expanding rapidly. Japanese companies have also opened special 100 Yen stores where all articles are priced at less than the equivalent of US\$1.

The American examples, coupled with the problems resulting from the economic problems in Japan, have resulted in substantial changes in the Japanese market. The number of wholesalers has dropped substantially, and is continuing to decline. The major department store chains, however, have not found a way to reverse their decline in sales and market share.

\subsection{Ending Comments}

Japan and the West have each benefited substantially from the adoption of ideas and techniques from each other. Both problems and opportunities have been motivating forces in the search for improved ways of operating. Basic differences remain, however, in some key managerial approaches. These differences are the result of variations in values, beliefs, and objectives. In most cases, there is not a convergence of management styles as much as development of hybrid styles which take varying customs and institutions into account.

\section{References}

1. Abegglen, James C. and George Stalk, Jr. (1985). Kaisha, The Japanese Corporation, (Basic Books).

2. Armstrong, David (2002). "Model for Success," The San Francisco Chronicle, January 13, pp. G1 \& G2.

3. Bird, Allan (Editor), Encyclopaedia of Japanese Business and Management, (London: Routledge, 2001).

4. Burt, Tim and David Ibison (2002). "Renault and Nissan going Dutch," Financial Times, May 29, p. 11.

5. Community Relations Department, New United Motor Manufacturing, Inc. (1990). Fremont, California: New United Motor Manufacturing, Inc., March, pp. 1,3.

6. Crane, Robert (2000). European Business Cultures, (Harlow, England: Financial Times-Prentice Hall).

7. $\quad$ Dawson, Chester, "Saying Sayonara," BusinessWeek, September 24, pp. 108-109.

8. Dessler, Gary (1983). Improving Productivity at Work, (Reston, Virginia: Reston Publishing Company).

9. Duerr, Edwin, and Mitsuko Saito Duerr (2002), "Japan's 'Economic Miracle' and Current Problems," Working Paper 02-06, (Aarhus, Denmark: The Aarhus School of Business, Department of International Business, Faculty of Business Administration, June).

10. Duerr, Edwin, and Mitsuko Duerr (2001), "New United Motor Manufacturing Inc.," in Bird, Allan (Editor), Encyclopaedia of Japanese Business and Management, (London: Routledge, 2001).

11. Duerr, Edwin and Mitsuko Saito Duerr (1998). "Det japanske livstidsansat-telsessystem-betydningen for konkurrenceeven" (The Japanese Lifetime Employment System - Implications for Competitiveness), Okonomi \& Politik (Economics and Politics), (Copenhagen, Denmark), Volume 71, Number 4, December.

12. Duerr, Mitsuko (1992). "NUMMI at Mid-life: Experience of the Joint Venture," in Japanese Foreign Investment in the United States, (Greenwich, Connecticut: JAI Press).

13. Duerr, Mitsuko (1991). "Business-Government Relations in Japan and the United States: A Comparative Analysis," SFSU School of Business Journal.

14. Duerr, Mitsuko Saito and Edwin Duerr (1991). "Applying Japanese Manufacturing Techniques in the U.S.," SFSU School of Business Journal.

15. Gelsanliter, David (1992). Jump Start: Japan Comes to the Heartland, (Tokyo: Kodansha).

16. Griffiths, John (2001). "Nissan's UK Plant 'is most productive in Europe'," Financial Times, June 28, p. 5.

17. Hendry, Joy (1995). Understanding Japanese Society, Second Edition, (London: Routledge).

18. Hsu, Robert C. (1994). The MIT Encyclopedia of the Japanese Economy, (Cambridge, Massachusetts: MIT Press).

19. “Japan, Inc.: Winning the Most Important Battle” (1971). Time, May 10, pp.50 - 55.

20. Kuo, Margaret and Edwin Duerr (2002). "7-Eleven Japan," in Gerald Albaum, Jesper Strandskov, and Edwin Duerr, International Marketing and Export Management, (Harlow, England: Financial Times-Prentice Hall)

21. Lane, Christel (1989). Management and Labor in Europe, (Aldershot, England: Edward Elgar Publishing Limited).

22. "Mazda gets late start on rebuilding" (2000). The Nikkei Weekly, November 27, p. 11. 
23. "Nissan UK," Business Horizons, January-February 1995.

24. Oliver, Nick and Barry Wilkinson (1992). The Japanization of British Industry, Oxford, England: Blackwell).

25. Reischauer, Edwin, and Marius Jansen (1995). The Japanese Today: Change and Continuity, (Cambridge, Massachusetts: Harvard University Press).

26. Scher, Mark, and Penelope Ciancanelli (1993). Association of Japanese Business Studies 1993 Best paper Proceedings.

27. Schonberger, Richard (1982). Japanese Manufacturing Techniques, (New York: The Free Press).

28. Taylor III, Alex (2002), "Nissan's Turnaround Artist," Fortune, February 25, pp. 46-51.

29. White, Merry (1987). The Japanese Educational Challenge, (New York: The Free Press).

30. Wolf, Marvin (1983). The Japanese Conspiracy, (Kent, England: New English Library).

31. Wong, Kai-Yiu (1989). "The Japanese Challenge: Direct Investment in the United States," in Kozo Yamamura (ed.), Japanese Investment in the United States, (Seattle, Washington: Society for Japanese Studies, University of Washington).

32. Yoshimura, Noboru and Philip Anderson (1997). Inside the Kaisha, (Boston, Massachusetts: Harvard University Press).

33. Yoshino, M.Y. (1968). Japan's Managerial System, (Cambridge, Massachusetts: The MIT Press).

\section{Notes}

Notes 